\title{
THE PHARMACOLOGY OF CORTISONE, CORTISOL (HYDROCORTISONE) AND THEIR NEW ANALOGUES
}

\author{
By Oliver Garrod, M.D., M.R.C.P. \\ Physician, Barnet General Hospital; late Research Fellow, Middlesex Hospital
}

In man the essential functions of the adrenal cortex stem from at least two hormones, cortisol (hydrocortisone) and aldosterone, these differing in their quality of action, mode of secretory regulation, and probable site of production within the gland. The adrenal sex hormones are of relatively minor physiological importance and will not be considered here.

The new synthetic analogues of cortisol are best assessed in relation to the essential duality of function of the adrenal cortex as revealed by the actions of its two principal hormones. The first function is concerned with a number of homoeostatic processes and with resistance to stress and is served by the secretion of cortisol. In the body cortisol is reversibly interconvertible with cortisone and is probably the active form of the hormone. Cortisol and cortisone, with their almost identical actions, are called glucocorticoids for their effects on carbohydrate metabolism. Though Ingle (1950) has likened use of the word glucocorticoid for these steroids to describing an elephant by the shape of its tail, yet it remains a useful generic term to cover all those diverse actions of cortisol and its analogues which seem to be inseparably linked with their carbohydrate effects.

The second or mineralocorticoid function of the adrenal cortex is concerned with the regulation of sodium and potassium balance, and depends largely on the secretion of aldosterone. A similar but less potent mineralocorticoid is desoxycorticosterone (DOC) which, though easily synthesized and used therapeutically as the acetate (DOCA), is secreted only in small amounts by the adrenal cortex. Further to their glucocorticoid properties, cortisol and cortisone also have a weak mineralocorticoid activity, which assumes an increasing importance when they are being produced in excess as in Cushing's syndrome, or administered in large doses

Intermediate in quality of action between cortisol and aldosterone, but much less potent, is corticosterone (Compound .B). Though it is the $\stackrel{\text { s }}{\circ}$ predominant glucocorticoid in a number of $\bar{B}$ mammalian species, in man it is of little importance 3 . for only small amounts are secreted (about I mg. $\stackrel{\dot{\omega}}{\omega}$ a day) (Migeon et al., 1956).

\section{The Secretion and Metabolism of Cortisol}

The rate of cortisol secretion is governed by

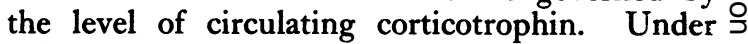
quiescent conditions the pituitary corticotrophin output varies inversely with the concentration of $⿱ ㇒$ cortisol in the blood, resulting in a fairly steady $\overparen{\Phi}$ rate of cortisol secretion from day to day. Over $\vec{\varphi}$ riding this basal 'feedback' regulation is th stress reaction whereby additional corticotrophir. is released, probably in response to stimulating neurohormones emanating from the hypothalamus and reaching the adenohypophysis by portal venous pathways. Under such extreme stimulation cortisol secretion may rise to about $250 \mathrm{mg}$. a day.

The capacity to suppress corticotrophin secretion is common to all known glucocorticoids, natural and synthetic, when given in doses which equal or exceed in equivalence the normal cortisol secretion of about $20 \mathrm{mg}$. a day. By only partially suppressing corticotrophin secretion smaller doses than these merely replace an equivalent amount of endogenous cortisol; hence they are usually ineffective therapeutically in patients with intact adrenal function. In effective doses they cause reversible atrophy of the zona fasciculata, whence cortisol is mainly derived, which lasts for many days after treatment has been stopped; $N$ hence the importance of slowly tapering off the dose over one to several weeks according to the duration of the preceeding treatment. If this precaution be neglected the patient is exposed to the risks of an acute adrenal crisis when faced during this period with severe stress, such as pneumonia or surgical trauma.

Likewise, during even moderately intensive glucocorticoid therapy the patient cannot step up 
his cortisol secretion in emergency, and must then be protected by raising the dosage, if needs be to the equivalent of $200 \mathrm{mg}$. of cortisone a day.

Independent of corticotrophic control there are wide diurnal variations in the rate of cortisol secretion which falls to low levels in the early morning hours before rising to a sustained peak at around 5 or 6 a.m. Whether this phenomenon should be allowed to influence the timing and distribution of dosage when steroids are being given in small amounts has yet to be decided.

Radioisotope studies have been of great value in elucidating the metabolism of cortisol (Migeon et al., 1956; Peterson and Wyngaarden, 1955 and 1956). Within the body the free steroid has a half life of about 1.4 hours, and is reduced to derivatives such as tetrahydrocortisol, tetrahydrocortisone, and allotetrahydrocortisol (Bush and Willoughby, 1957), which combine in the liver with glycuronic acid to form glucuronides. Together these metabolites account for about 36 per cent. of the secreted hormone and are excreted in the urine where they can be measured as 17 -hydroxycorticoids (Reddy, 1954), or, together with the cortol and cortolone derivatives, as 17 -ketogenic steroids (Norymberski et al., 1953). Only about 4 per cent. of the metabolites of cortisol can be accounted for as 17 -ketosteroids, and about 0.15 per cent. of the hormone is excreted in the free state (Wade and Kellie, 1957). Impaired liver function and myxoedema retard the conjugation, and renal failure the excretion, of these metabolites, hyperthyroidism having the opposite effect (Peterson et al., 1955). By means of radio-isotope studies it has been shown that the high plasma 17-hydroxycorticoid levels of late pregnancy are due to delayed metabolism, and not increased secretion, of cortisol (Migeon et al., 1957).

\section{Physiological and Pharmacological Actions of Cortisol}

Despite the protean activities of cortisol, little is known about the biochemical processes which mediate these effects within the cells, though there is evidence that a number of enzyme systems are involved (Ingle, 1950). To quote Ingle (1950): - The consequences of cortical hormone action spread through the organism in a manner reminiscent of the waves caused by the impact of a stone in a pool of water, but the point of impact of the hormone remains unknown for the present.' In most instances cortisol would seem to assist rather than initiate the processes which it affects (Sayers, 1950). Except for the electrolyte effects, the actions of cortisol are common to all the known glucocorticoids, whether natural or synthetic, varying in strength but not in quality from one such compound to another.
Biochemically these steroids influence the metabolism of protein, fat, carbohydrate, purines, electrolytes and water, and exert a direct calorigenic action (Evans et al., I957). In excess they inhibit tissue healing and body growth, influence the local and general response to infection, and raise the body's resistance to stress; they help in maintaining normal functions of the brain, heart and circulation, and stimulate the gastric secretions.

\section{Metabolic Effects}

Glucocorticoids stimulate protein katabolism, thereby increasing nitrogen output and glucose formation (gluconeogenesis). In excess this leads to muscle wasting, weakening of connective and vascular tissue, osteoporosis and the formation of wide purple striae. Aminoacid, creatine and uric acid excretion are increased. This last effect may be useful when treating acute gout, if not neutralised by increased uric acid formation.

The complex actions of glucocorticoids on carbohydrate metabolism can be only partly accounted for by increased gluconeogenesis, for these steroids also antagonize insulin, promote glycogen storage, and lower the renal glucose threshold (Fourman et al., 1950). Large doses diminish glucose tolerance and cause mild glycosuria尺 Frank diabetes seldom results (less than I per cent treated cases), and when it does is usually uno accompanied by ketonuria (Brookman et al. 1953). Fat mobilization and ketone combustion are accelerated, and starvation ketosis inhibited (Kinsell et al., I95 I). A centripetal redistribution of body fat contributes towards the Cushingoid habitus which is a feature of steroid overdosage.

\section{Water and Electrolytes}

The complicated actions of cortisol and cortisone on water and electrolyte metabolism, though mainly located within the kidney, are not confined to this organ, for these steroids have been shown to increase the extracellular fluid volume independently of changes in, external water and electrolyte balance (Levitt and Bader, 195I). They also diminish the sodium : potassium ratio in sweat and saliva (Conn and Fajans, 1952).

Acting as weak mineralocorticoids, cortisol and cortisone increase the renal tubular reabsorption of sodium, resulting in fluid retention. Often this effect is only transient and followed by diuresis; frank oedema seldom follows unless other factors are present. Paradoxically, and notably in Addisonian patients receiving DOCA, these steroids may initially increase sodium excretion, probably by raising the glomerular filtration rate (Garrod et al., 1955a). The basis for their 
sodium-diuretic action in cardiac, scirrhotic and nephrotic oedema, is not yet understood.

Potassium excretion is increased by a direct renal tubular action, augmented by potassium release from protein breakdown. As opposed to pure mineralocorticoids such as aldosterone and DOC, glucocorticoids act specifically and permissively on water diuresis and so protect against water intoxication. Without them there is great delay in excreting a water load, and when they are given in excess water diuresis is accelerated. The underlying osmotic mechanisms are only partly understood but seem to involve a direct action on the renal tubules.

\section{Bone and Calcium Metabolism}

Here, again, the effects of glucocorticoids are complex and obscure. Prolonged treatment results in negative calcium, phosphorus and nitrogen balances and eventually osteoporosis. These steroids also antagonize the action of vitamin D and its analogues (Dickel, r95I) and so neutralize the effects of antitetanic treatment in hypoparathyroidism (Moehlig and Steinbach, 1954). By inhibiting excessive calcium absorption from the gut, they correct the defect'which causes hypercalcaemia in some cases of sarcoidosis (Hellman et al., 1956).

\section{The Circulation}

6 The actions of glucocorticoids on the circulation are largely permissive. Without them the blood pressure and glomerular filtration rate fall sharply. Similarly hypertension can be corrected by bilateral adrenalectomy followed by minimal cortisone maintenance (Harrison et al., 1952); yet, provided renal function is good, hypertension seldom follows the use of these steroids in man, despite their potentiating the pressor action of noradrenaline (Kurland and Freedberg, 195I). Large doses can raise the glomerular filtration rate to supernormal levels. Cerebral blood flow increases, but cerebral oxygen and glucose utilization are not affected (Schieve et al., I95 I).

\section{Blood and Blood Vessels}

Glucocorticoids in excess cause eosinopenia and regression of lymphoid tissue, this last action explaining their usefulness in the treatment of lymphosarcoma and lymphatic leukaemia. They stimulate neutrophil and red cell production and can induce a mild reversible polycythaemia. They have no consistent effects on platelet formation, purpura being suppressed because of their action in : depressing capillary fragility (Zweichach $e t a l$, rg53).
Anti-inflammatory and Anti-allergic Actions

Glucocorticoids modify both general and local responses to inflammatory agents. Under their 0 suppressive influence fever abates and there is a $\frac{1}{2}$ fall in the erythrocyte sedimentation rate which can be correlated with a decrease in plasma fibrinogen and gamma-globulin concentrations (Fletcher et al., 1952); the plasma albumin tends to rise.

The local anti-inflammatory effects of these steroids are related to several actions :- a lessening of fibroblast response and cellular reaction, a diminution in the number of mast cells and consequently in the amount of tissue hyaluronic acid, and an inhibition of specific antibody synthesis. Whilst these actions may be desirable in the treatment of collagen diseases and of excessive connective tissue proliferation in other disorders; they predispose to the spread of tuberculosis and other bacterial infections unless appropriate antibiotic cover is provided.

The remarkable antiallergic properties of the glucocorticoids are probably related to their modifying action on antigen-antibody reactions and on histamine release, and may be lifesaving in such conditions as status asthmaticus and beneficial in many other disorders.

\section{Central Nervous System}

Glucocorticoids increase cerebral excitability predisposing to fits and.psychoses in susceptible subjects. Euphoria and insomnia are common accompaniments of steroid therapy and less often agitated depression. The electroencephalograph shows characteristic changes in Addison's disease (Forsham et al., 1949) and in patients on large doses of cortisone (Boland and Headley, r949). The pain-relieving properties of these steroids seem to be related to their local anti-inflammatory action rather than to any' direct effects on the sensory nervous system.

\section{Gastric Secretions}

Glucocorticoids increase the concentrations of pepsin and hydrochloric acid in the stomach, as reflected in a rise of uropepsin excretion (Eastcott et al., 1953). This action, which is independent of the route of steroid administration, predisposes to peptic ulceration in those susceptible and is one of the major risks of steroid therapy.

\section{Secondary Endocrine, Effects}

Although exerting a direct calorigenic action glucocorticoids in high dosage also suppress thyroid function; as shown by diminished radioiodine uptake (Berson and Yalow, 1952) and a fall in the plasma protein-bound iodine (Hill et :al., 1950). Gonadal function may also be depressed. 
The androgenic side-effects of large doses, such as acne and hirsutism, may be due to 17 -ketosteroid metabolites of cortisone.

\section{Aldosterone}

Aldosterone, the other major adrenocortical hormone, is the principal regulator of sodium and potassium balance, and is secreted mainly by the zona glomerulosa (Ayres et al., 1957). Although cortisol also contributes towards sodium retention and in excess may even become the predominant mineralocorticoid, yet its rate of secretion is unrelated to the changing requirements of sodium and potassium balance.

By contrast with cortisol, the secretion of aldosterone is geared to the needs of the extracellular fluid volume, or more precisely probably of the arterial side of the vascular compartment (Bartter, 1956). The mechanisms which regulate this secretion are unknown but seem to be largely independent of pituitary control since they remain intact after hypophysectomy. The physiological stimuli for increased aldosterone secretion are a loss or deprivation from the body of sodium, water, or blood, and a high potassium intake. Conversely, a high sodium intake, pitressininduced water intoxication, and potassium deprivation all inhibit the secretion (Bartter, 1956).

Prolonged oversecretion of aldosterore, as in Primary Hyperaldosteronism, leads to severe potassium deficiency, alkalosis, and excessive sodium retention which, being mainly intracellular, seldom gives rise to oedema. Similar effects occur with overdosage of DOCA or fluorohydrocortisone (vide infra), and can likewise be corrected by severely restricting the sodium intake.

\section{Synthetic Analogues of Cortisol and Cortisone}

By effecting minor adjustments to the steroid ring or its attachments the chemist has been able to a remarkable degree to enhance and modify the actions of these steroid hormones. Qualitatively, however, these changes have only brought about a shift of balance between their glucocorticoid and mineralocorticoid potencies. So far only three of the many new compounds have found their way into general use: the two delta-I steroids, prednisolone and prednisone, and 9-alpha-fluorohydrocortisone (fludrocortisone). Two other compounds have recently been made available.*

\section{The Delta-i Compounds: Prednisolone and Prednisone}

These compounds̀, which are analogues of

*These are triamcinolone ( 6 hydroxy-9-alpha-fluoroprednisolone) and 6-methyl prednisolone. cortisol and cortisone respectively, were discovered in the laboratories of the Schering Corporation (Herzog et al., 1955). The introduction of a double bond between the first two carbon atoms of the steroid ring increases the glucocorticoid potencies of cortisol and cortisone by at least 4 to 5 times, yet without enhancing their mineralocorticoid activities. Thus, prednisolone and prednisone can be given in therapeutic dosage without fear of causing excessive sodium retention or potassium depletion. In all other ways their actions resemble those of the parent steroids, but with 4 to 5 times the potency. Except when treating adrenal failure, sodium retention and potassium depletion are undesirable side-effects of steroid therapy, and especially in debilitated, hypertensive, oedematous or cardiac patients, or when the aim of treatment is to promote sodium diuresis. These new compounds are therefore rapidly replacing cortisone and cortisol in general use, thereby obviating the need for sodium restriction and supplementary potassium unless heroic doses are being used as in the treatment of certain blood dyscrasias.

Recent studies have shown that prednisone and prednisolone are largely excreted in unmetabolized form, giving rise to fewer tetrahydro-derivatives (Slaunwhite and Sandberg, I957; Vermeulen, 1956). As with the natural steroids, prednisolone and prednisone are freely interconvertible within the body (Gray et al., 1956).

\section{9-alpha-fluorohydrocortisone}

The remarkable effects of adding a halogen atom in the 9-alpha position to the cortisol molecule were discovered by Fried and Sabo (1953). Of these derivatives only the chlorinated and fluorinated compounds were found to exceed the natural steroid in potency. Whereas the glucocorticoid activity of 9 -alpha-fluorohydrocortisone (FHC) is about ro times that of cortisone, the mineralocorticoid açtivity exceeds that of the parent compound by at least roo times (Garrod et al., 1955b) and is slightly greater than that of aldosterone.

Despite its enhanced glucocorticoid potency the extreme electrolyte activities of FHC preclude its systemic use as a substitute for cortisone (Ward et al., 1954). However, since it can be given by mouth, it is an ideal substitute for DOCA in treating adrenal insufficiency at doses of about 0.1-0.2 mg. a day. The cortisone-like action of such amounts is very small, so cortisone must also be given to achieve adequate replacement.

This contraindication applies less when the steroid is used topically, as in skin disease, for it is little absorbed into the circulation. Excessive sodium retention has, however, been reported 
following liberal use of FHC ointments in patients with extensive ulcerated skin lesions.

A third use of FHC, which takes advantage of its enhanced glucocorticoid activity, is in tests to differentiate adrenocortical tumours from adrenocortical hyperplasia (Renold et al., 1955). Using this compound the metabolic end-products are small enough rot to disguise the falls in 17ketosteroid and I 7 -hydroxysteroid excretion which follow the steroid-induced suppression of endogenous corticotrophin in patients with adrenal hyperplasia.

\section{Some More Recent Cortisol Derivatives}

By the addition of a 6-methyl group to cortisol or prednisolone or a $16-\mathrm{OH}$ group to $\mathrm{FHC}$ or 9-alpha fluoroprednisolone compounds can be obtained with even greater glucocorticoid potency than prednisolone, and without excessive mineralocorticoid activity (Spero et al., 1956; Bernstein et al., 1956). These compounds, which have not yet been subjected to full clinical trial, are unlikely to offer advantages over prednisolone as they seem to have no important qualitative differences in their glucocorticoid actions.

Then, there are the 2-methyl derivatives of cortisol and FHC, which are the most potent mineralocorticoids yet discovered (Liddle et al., 1956). The second of these two compounds is several thousand times as active as cortisol on electrolyte metabolism, and a single oral dose is effective for about 48 hours. Many more analogues of cortisol are being prepared and subjected to biological assay.

\section{Modes of Administration of Steroid Hormones}

For pharmacological use, cortisone and FHC are prescribed as the acetate esters, prednisone and prednisolone usually as the free compounds, and cortisol in either form. Orally, they act within 2 to 3 hours and are effective for about 12 hours, depending on the dose. To maintain adequate blood levels with oral therapy large doses should be given 12-hourly and small doses 8-hourly, though FHC can be given once a day.

With intramuscular injection the rate of absorption is far slower and the effects of a single dose may last, though feebly, for several days. In the case of cortisol the free compound is more rapidly absorbed than the less soluble acetate. This route of administration offers no real advantages over the oral route, and is rarely indicated.

To obtain a rapid effect, as in the treatment of acute adrenal crisis and status asthmaticus it is necessary to use intravenous cortisol, either as the free compound (alcohol) or preferably as the sodium succinate ester or intravenous prednisolone-2 I-phosphate. I00 mg. of cortisol are dis- solved in $500 \mathrm{ml}$. of 5 per cent. dextrose, and acto maximally. when infused at a rate of 10 to $12 \mathrm{mg}$. an hour. The sodium succinate ester is very soluble in water; $100 \mathrm{mg}$. given intravenously, dissolved in $2 \mathrm{ml}$. of distilled water or saline, $c$ begins to act within about half an hour (Orr et al., 1955). Prednisolone-21-phosphate has the advantage of being stable in solution and veryc soluble.

For topical and intraarticular use, only cortisol $\frac{\overline{\bar{c}}}{\frac{7}{}}$ or its analogues, prednisolone and FHC are effec- $₫$ tive, their effective concentrations in suspension or as ointments being roughly inversely propor- tional to their glucocorticoid potencies (vide supra). Cortisol and FHC are used in acetate $\vec{\omega}$ form, prednisolone as the free compound ors acetate.

\section{BIBLIOGRAPHY}

AYRES, P. I. GARROD, O., PEARLMAN, W. H. TAIT S. A. S., TAIT, J. F., and WALKER, G. (I957), Ciba Found.'W Colloq. Endocrin., 'Hormones in Blood,' Churchill, London. NN BARTTER, F. C. (1956), Metab., 5, 369.

BERNSTEIN, S., et al. (1956), F. Amer. chem. Soc., 78, 5693.

BERSON, S. A., and YALOW, R. S. (1952), 7. clin. Endocr., 12, 407. BOLAND, E. W., and HEADLEY, N. E. (1949), F. Amer. med. Ass., I4I, 301. BROOKMAN, J. J. DRACKMAN, S. R., SCHAEFER, L. E., Č
and ADLERSBURG, D. (1953), Diab., 2 , roo.

BUSH, I. E., and WILLOUGHBY, M. (1957), Biochem. . ., in press. $\frac{\vec{\Phi}}{\Phi}$

CONN, J. W., and FAJANS, S. S. (1952), Ann. Rev. Physiol., 14, 453.

DICKEL, H. (195I), Mönch. med. Wschr., 93, I.

EASTCOTT, H. H. G., FAWCETT, J. K., and ROB, C. G. (1958). Lancet, i, 1068.

EVANS, E. S., CONTROPOULOS, A. N., and SIMPSON, N. (1957), Endocrin., 60, 403.

FLETCHER, A. A., DAUPHINEE, J. A., and OGRYZLO, M. A. (1952), 7. clin. Invest. 31, 561. L. L.. ROCHE, M. REISS R. S., SLESSOR, A., FLINCK, E. B., and THORN, G. W. (1949), F. clin. Endocr., 9, 660.

FOURMAN, P., BARTTER, F. C., ALBRIGHT, F., DEMPSEY, $\overrightarrow{\vec{\theta}}$ E., CARRÖLL, E., and ALEXXNDER, J. A. (1950), $\mathscr{f}$. clin. Invest., 29, 1462 .

FRIED, J., and SABO, E. F. (1954), f. Amer. chem. Soc., 76, 1455. GARROD, O., DAVIES, S. A., and CAHILL, G., Jr. (r955a),

GARROD, O., NABARRO, J. D. N., PAWAN, G. L. S., and WALKER, G. (r955b), Lancet, 2, 367 .

GRAY, C. H., GREEN, M. A. S., HOLNESS, N. J., and. LUNNON, J. B. (1956), Ұ. Endocr., I4, 146.

GRAY, S. J., BENSON, J. A., REIFENSTEIN, R. W., and SPIRO, H. M. (1951), $\mathscr{f}$. Amer. med. Ass., 147, 1529.

HARRISON, J. H., THORN, G. W., and CRISCITIELLO, M. G. (1952), F. Urol., 67, 405.

HELLMAN, L., BRADLOW, H. L., FRAZELL, E. L., and GALLAGHER, T. F. (1956), $\mathfrak{f}$. clin. Invest., 35, 1033.

HENNEMAN, P. H., DEMPSEY, E. F., CARROLL, E. L., and ALBRIGH T, F.'(1956), Ibid., 35, 1229.

HERZOG, H. L., NOBILE, A., TOLKSDORF, S., CHARNEY, W., HERSHBERG, E. B., PERLMAN, P. L., and PECHET, M.' M. (1955), Science, 121, 176.

HILL, S. R., REISS, R. S., FORSHAM, P. H., and THORN, G. W. (1950), $\mathcal{Y}$. clin. Endocr., 10, 1375 .

INGLE, D. J. (1950), Ibid., 10, 1312.

INSELI $W$ MARGEN, $S$, PARTRIDGE,'J. (1951), Proc. 2nd Clin. ACTH Conf., $i, 308 .<$ KURLAND, G. S., and FREEDBERG, A. S. (1951), Prac. Soc. exp. Biol. (N.Y.), 78, 28.

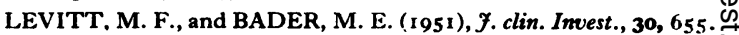

LIDDLE, G. W., RICHARDS, J. E., and TOMKINS, G. M.T (1956), Ұ. clin. Endocr., 16, 917.

Bibliography continued on page 309

\section{.}


cretion. A similar effect may also be observed when cortisone is given to a hypercalcaemic patient with multiple bony metastases if the steroid inhibits the growth of the neoplastic tissue. In hyperparathyroidism, on the other hand, cortisone does not influence the hypercalcaemia.

\section{BIBLIOGRAPHY}

ANDERSON, J., DENT, C. E., HARPER, C., and PHILPOT, G. R. (1954), Lancet, ii, 720.

BARTTER, F. (1956), Metabolism, 5, 369.

BAYLISS, R. I. S. (1957a), Proc. roy. Soc. Med. 5o, 76r.

BAYLISS, R. I. S. (1957b), in 'Modern Trends in Endocrinology,' London, Butterworth.

BECK, R. N., and MONTGOMERY, D. A. D. (1956), Brit. med. F., ii, 921.

COPE, C. L. (1956), Ibid., ii, 193.

FOURMAN, P., and HORLER; A. R. (1954), Lancet, i, 334.
GURLING, K. J., GORE, M. B. R., and BARON, D. N. (1958), 7. Endocr. 16, 304.

JAILER, J. W., GOLD, J. J., and WALLACE, E. Z. (1954), Amer. F. Med., 16, 340.

KUPPERMAN, H. S., BLATT, M. H. G., VESELL M., GAGLIANI, J., WEISBADER, $\dot{H}$., and V'OSBURGH, $L$.' (1955), 7. clin. Endocr., 15, 91 1 .

LANCET (1955), i, 6.

LEITH, W., and BECK, J. C. (1957), Ұ. clin. Endocr., 17, 280.

LIDDLE, G. W. and RICHARDS, J. E. (1956), Science, 123, 324. NABARRO, J. D. N., and WALKER, G. (1957), Brit. med. f., OWEN, ${ }^{17}$ j.

EN, J. A., ENGEL, F. L., and WEBSTER, T. B. (1957), F. clin. Endocr., 17, 272.

PRADER, A. (I953), Helv. paediat. Acta 8,386

SEGALOFF, A., GORDON, D., and HORWITT, B. N. (1955), F. Amer. med. Ass., 157, 1479.
SPENCE, A. W., JENKINS, J. S., and ROBINSON, A. M. (1956), Brit. med. F., ii, 1348 .

WERNER,' S. C. (1953), $\mathcal{F}$. clin. Endocr., 13, 1332.

WILKINS, L., LEWIS, R. A., KLEIN, R., GARDNER, L. I., CRIGLER, J. F., ROSENBERG, E., and MIGEON, C. J' (195I), Ibid., Ir, I.

\section{ANAESTHETICS \\ (Postgraduate Medicál Journal)}

Price: 3s. 11d. post free

THE MODERN VIEW OF ANAESTHESIA

G. S. W. Organe, M.D., D.A., F.F.A.R.C.S.

THE PRODUCTION OF UNCONSCIOUSNESS

B. G. B. Lucas, D.A., F.F.A.R.C.S.

\section{ANALGESIA}

J. B. Wyman, M.B.E., D.A., F.F.A.R.C.S. MUSCLE RELAXATION IN SURGERY

Angus Smith, F.F.A.R.C.S.

CONTROL OF THE BLOOD PRESSURE AND CONTROLLED HYPOTENSION

C. F. Scurr, M.V.O., D.A., F.F.A.R.C.S.

\section{CHLORPROMAZINE AND ALLIED SUBSTANCES}

John Beard, M.D., D.A., F.F.A.R.C.S., D.C.H.

CONTROLLED HYPOTHERMIA

E. J. Delorme, M.D., F.R.C.S.(C.)

MANAGEMENT OF THE APNOEIC

PATIENT

Ronald Woolmer, D.A., F.F.A.R.C.S.

THE USE OF ANTIDOTES IN

ANAESTHESIA

B. A. Sellick, D.A., F.F.A.R.C.S.

Published by

THE FELLOWSHIP OF POSTGRADUATE MEDICINE

60, Portland Place, London, W.1

Bibliography continued from page 304-Oliver Garrod, M.D., M.R.C.P.

MIGEON, C. J., BERTRAND, J., WALL, P. E., STEMPFEL R. S., and PRYSTORSKY, H. (1957), Ciba Found. Colloq Endocrin., 'Hormones in Blood,' in press, Churchill, London,

MIGEON, C. J., SANDBERG, A. A., DECKER, H. A., SMITH, D. F., PAUL, A. C., and SAMUELS, L. T. (I956), 7. clin. Endocr., 16,1137 and $\mathrm{I} 29 \mathrm{I}$.

MOEHLIG, R. C., and STEINBACH, A. L. (1954), F. Amer. med. Ass., $154,42$.

ORR, R. H., DI RAIMONDO, V., FLANAGAN, M. E., and FORSHẢM, P. H. (1955), Ibid., 15, 763 .

PETERSON, R. E., and WYNGAARDEN, J. B. (1955), f. clin. Invest., 34, 957 .

PETERSON, R. E., and WYNGAARDEN, J. B. (1956), Ibid., 35, 552.

PETERSON, R. E., WYNGAARDEN, J. B., GUERRA, S. L., BRODIE, B. B., and BUNIM, J. J. (1955), Ibid., 34, 1779.

REDDY, W. J. (1954), Metab., 3, 489.
RENOLD, A. E., HAYDER, N. A., REDDY, W. J., GOLDFIEN, A., ST. MÄRC, J. R., and LAIDLAW, J. C. (r955), $A n n$. N.'Y. Acad. Sci., 61, 582.

SAYERS, G. (1950), Physiol. Rev., 30, 241 . SCHIEVE, J. F., SCHEINBURG, P., and WILSON, W. P. (195 I),
f. clin. Invest., 30, 1527 .

SLAUNWHITE, W. R., Jr., and SANDBERG, A. A. (1957), 7. clin. Endocr., 17,395 .

SPERO, G. B., THOMPSON, J., L., MAGERLEIN, B. J. HAUZE, A. R., MURRAY, H. C., SEBEK, O. K., and HOGG, J. A. (1956), F. Amer. chem. Soc., 78, 6214.

VERMEULEN, A. (1956), Acta endocr., 23, I 13.

WADE, A. P., and KELLIE, A. E. (1957), personal communication.

WARD, L. E., POLLEY, H. F., SLOCUMB, C. H., HENCH P. S., MASON, H. L., MATTOX, V. R., and POẄER, M. H' (1954), Proc. Mayo Clin., 29, 649.

ZWEICHACH, B. W., SCHORR, E., and BLOCK, M. M. (1953), 